\title{
Carbon Storage and Climate Change Mitigation Potential of the Forests of the Simien Mountains National Park, Ethiopia
}

\author{
Habtamu Assaye ${ }^{1}$, Zerihun Asrat ${ }^{2}$, * \\ ${ }^{1}$ College of Agriculture and Environmental Sciences, Bahir Dar University, Bahir Dar, Ethiopia \\ ${ }^{2}$ School of Forestry, Hawassa University, Hawassa, Ethiopia
}

Email address:

zerasrat@yahoo.com (Z. Asrat)

${ }^{*}$ Corresponding author

\section{To cite this article:}

Habtamu Assaye, Zerihun Asrat. Carbon Storage and Climate Change Mitigation Potential of the Forests of the Simien Mountains National Park, Ethiopia. Agriculture, Forestry and Fisheries. Vol. 5, No. 2, 2016, pp. 8-17. doi: 10.11648/j.aff.20160502.11

Received: February 18, 2016; Accepted: February 29, 2016; Published: March 30, 2016

\begin{abstract}
The study assessed land cover change, carbon stock and sequestration potential of Simien Mountains National Park (SMNP), Ethiopia. Landscape was stratified into four zones based on the vegetation ecology and land uses: Afro-alpine grassland (AAGL), Afro-alpine woodland (AAWL), Afro-montane forest (AMF) and Cultivated and overgrazed land (COL). 40 sample plots were taken randomly (10 from each zone). Nested plot design with size of $50 \mathrm{~m} * 50 \mathrm{~m}$ and subplots of $20 \mathrm{~m} * 20 \mathrm{~m}, 10 \mathrm{~m} * 10 \mathrm{~m}, 5 \mathrm{~m} * 5 \mathrm{~m}, 2 \mathrm{~m} * 2 \mathrm{~m}$ and $1 \mathrm{~m} * 1 \mathrm{~m}$ was used for the measurement of trees of different diameter classes. Soil sampling was done at the four corners of the $10 \mathrm{~m} * 10 \mathrm{~m}$ subplots to a depth of $30 \mathrm{~cm}$ and taken to laboratory for analysis along with litter and undergrowth. Allometric equation was used for determination of above ground biomass (AGB) carbon. Below ground biomass (BGB) carbon was taken as $24 \%$ of AGB carbon. Land cover change was analyzed comparing satellite images of different periods. It was found that the COL has increased from $20 \%$ in 1972 to $48 \%$ in 2013. As a result, the AMF and AAWL have shrunk by nearly 50\%. A future projection with a simple linear model indicated 73 ha and 251.3 ha of annual deforestation rate in the AAWL and AMF zones respectively, implying that it will take only 71 and 49 years for the AMF and AAWL respectively to be completely lost. Above ground carbon (AGC), below ground carbon (BGC) and soil organic carbon (SOC) holds $34.4 \%, 8.3 \%$ and $55.2 \%$ of the total carbon stock respectively. Dead wood and Litter Biomass together contributed only to the 2.2\%. From land cover point of view AMF, AAGL, AAWL and COL stored 47.5\%, 22\%, 20.9\% and $9.6 \%$ of the total carbon stock in the area respectively. A linear regression of Shannon diversity index against total carbon and AGC was calculated for AMF zone and as such no strong relationship was found for the total C $\left(\mathrm{R}^{2}=0.242\right)$ and also AGC $\left(\mathrm{R}^{2}\right.$ $=0.337$, but it appeared that the stored carbon tends to decrease as the Shannon diversity index increases.
\end{abstract}

Keywords: Land Cover Change, Carbon Sequestration Potential, Simien Mountains National Park, Tree Species Diversity

\section{Introduction}

Climate change has been proved by scientific evidences and unequivocally accepted by the global community as a common issue of interest. Since the industrial revolution, the burning of fossil fuels and the destruction of forests have caused the concentrations of heat-trapping Green House Gases (GHGs) to increase significantly in our atmosphere, at a speed and magnitude much greater than natural fluctuations would dictate. If concentrations of GHGs in the atmosphere continue to increase, the average temperature at the Earth's surface will increase by 1.8 to $4^{\circ} \mathrm{C}$ by the end of the century [24]. Thus, the rapid increase in global surface temperature is mainly due to the rise in the amount of carbon dioxide in the atmosphere primarily due to anthropogenic activities [39]. As a result of change in global climate there has been a widespread and growing concern that has led to extensive international discussions and negotiations. In seeking solutions for this, the overwhelming priority is to reduce emissions of GHGs and to increase rates of carbon sequestration. The concerns have led to efforts of reducing 
emissions of GHGs, especially $\mathrm{CO}_{2}$, and measuring carbon absorbed by and stored in forests, soils, and oceans. To slow down the rise of GHGs concentrations in the atmosphere, and thus possible climate change, is to increase the amount of carbon removed by and stored in forests [23, 4, 25].

As a natural solution, the role of trees and forests in the process of carbon cycle is quite significant as it stores more carbon among the terrestrial ecosystems [26, 41, 35]. This will make forest ecosystems to be the largest terrestrial carbon pool. Protected areas, with their all and diverse ecosystems including forests are vital systems to capture and store carbon from the atmosphere and to help people and ecosystems adapt to the impacts of climate change [11]. Ethiopia, being party to the United Nations Environmental Program and signatory to its treaties and protocols, is striving to contribute to the international effort of climate change adaptation and mitigation. It has adjusted its development strategy aiming at meeting net zero emissions by 2030 and developed climate resilient green economy (CRGE) strategy. Conserving and enriching existing forests, establishing new forests, enhancing of the existing protected areas and establishing new ones are some of the measures undertaken by the government. The role of forests to capture and store carbon from the atmosphere has been studied by several researchers $[43,30,2,33,1]$. However, studies on carbon storage process at a landscape level for instance in a protected area with different land covers are lacking. Therefore, this study was undertaken to assess the carbon storage potential of Simien Mountains National Park (SMNP) in Ethiopia through its different land cover zones and the overall dynamics of land cover changes.

\section{Methodology}

\subsection{Site Description}

The study was conducted in SMNP found in Amhara National Regional State, north Gondar, Ethiopia located at about $846 \mathrm{~km}$ North of Addis Ababa. The park has an area of $412 \mathrm{~km}^{2}$ and geographically situated around $13^{\circ} 11 ' \mathrm{~N}$ and $38^{\circ} 04^{\prime} \mathrm{E}$. SMNP was established in 1966 and officially recognized in 1969 for its rich of rare and endemic wildlife species, diverse fauna and flora composition and for its spectacular landscape and unique scenery. The park was inscribed in the World Heritage List for fulfilling criterion III (exceptional beauty) and criterion IV (importance for biodiversity) in 1978. SMNP is the first natural World Heritage Site inscribed in Ethiopia. The climatic condition within the park ranges from woina-dega at lower altitude (1500 - 2400 m.a.s.l) to wurch zone at the upper elevations (above 3700 m.a.s.1). High-dega and temperate climate zones are found in between the two. Mount Ras-Dejen, with 4620 m.a.s.1, the highest peak in the area as well as in the country is also part of this park. Approximately $75 \%$ of precipitation in the area falls between June and September as predominantly hail, rain and mist resulting in a mean annual rainfall of $1550 \mathrm{~mm}$. Temperatures are relatively consistent throughout the year, however there are large diurnal fluctuations ranging from a minimum of $-2.4-4^{\circ} \mathrm{C}$ at night to a maximum of $11-18^{\circ} \mathrm{C}$ during the day $[17,16,27,7,21]$. The national park is important conservation site for rare and endemic animals that made the park as last habitat such as Walia Ibex (Capra walie), Chelada baboon (Theropithecus gelada), Ethiopian Wolf (Canis simensis), etc.

\subsection{Stratification of the Area}

Considering vegetation differences and land uses within the study area, SMNP was stratified into four zones. These zones include, the Afro-alpine grassland (AAGL) occupying the highest altitude ranges, Afro-alpine woodland (AAWL) that is dominated by the Erica arborea trees, the Afromontane forest (AMF) surrounding the mountain base and steep slopes, and Cultivated and overgrazed land (COL). Image analysis for land cover change study and stratification of the area was done using satellite image of four different years (1972, 986, 2000 and 2013) with ERDAS Imagine and Arc GIS software.

\subsection{Sampling Technique}

A square grid of $1 \mathrm{~km} * 1 \mathrm{~km}$ was drawn on the map of the park considering the outer gridlines as reference. $10 \%$ of the square grids were considered for the sampling and proportionally distributed to the different vegetation zones. Accordingly, 41 samples were needed for SMNP, which would have been distributed as 7, 9, 5 and 20 plots for the AAGL, AAWL, AMF and COL respectively. However, taking into consideration the fact that there is high variability and carbon stock in the AAWL and AMF zones as compared to the COL, and also in consideration of taking fairly equal minimum number of plots, 10 samples were taken randomly from each zone making it 40 total sample plots. Nested plot design, which is appropriate for inventories in natural forests where there is high variability in tree size, distribution and structure, was used. Forest carbon assessments in particular use nested plot designs that present variable size subplots for the different tree size classes and also for the different forest carbon pools. Accordingly, 50m*50m (the outer most) plot was used for trees above $30 \mathrm{~cm} \mathrm{DBH}, 20 \mathrm{~m} * 20 \mathrm{~m}$ subplot was used for trees with DBH between $10 \mathrm{~cm}$ and $30 \mathrm{~cm}, 10 \mathrm{~m} * 10 \mathrm{~m}$ subplot was used for trees between $5 \mathrm{~cm}$ and $10 \mathrm{~cm} \mathrm{DBH}$, $5 \mathrm{~m} * 5 \mathrm{~m}$ subplot was used for small trees of DBH between $2 \mathrm{~cm}$ and $5 \mathrm{~cm}, 2 \mathrm{~m} * 2 \mathrm{~m}$ subplot was used for regeneration and undergrowth and the inner most $1 \mathrm{~m} * 1 \mathrm{~m}$ subplot was used for litter. Tree height was also measured along with DBH. Soil samples were taken at four corners of the $10 \mathrm{~m} * 10 \mathrm{~m}$ subplot to a depth of $30 \mathrm{~cm}$, and one composite sample was taken for soil carbon determination.

\subsubsection{Vegetation Data Collection and Identification}

The estimations of above and below ground carbon depend on the above ground biomass of living tree species. To estimate the above ground biomass all tree species within selected sample plots were identified, measured and recorded as specified above. Plant identification was done according to 
Flora of Ethiopia and Eritrea [12, 13, 14].

\subsubsection{Carbon Stock Measurement}

Carbon stock has been assessed in five forest carbon pools, which is in accordance with the IPCC 2006 guideline [15]. Hence, the major activities of carbon measurement during the field data collection were focused on above-ground tree biomass, below-ground biomass, dead wood, litter, and soil organic carbon as stated here below.

\section{$i$. Aboveground vegetation biomass $(A G B)$ carbon}

Carbon in the AGB was assessed through measurement of standing trees and shrubs using proper mensuration techniques. DBH and height of trees were measured according to their size class in the respective subplots. Therefore, species type, diameter at breast height (DBH) and height of trees $(\mathrm{H})$ were the interest of measurement for trees. GPS was used to identify exact location of plots. DBH was measured with caliper/diameter tape depending on the size of the tree. Tree height was measured using haga hypsometer, and slope was measured with suunto clinometer to adjust the size of the plots to proper size. Carbon stock assessments in Africa are highly variable and have high degree of uncertainty due to lack of consistency in techniques of inventory and lack of site and species specific allometric equations. There are few species specific allometric equations developed in Africa, and most of the carbon stock assessments used general allometric equations despite the high degree of variability in site growth conditions and growth characteristics of species [22]. Equations indicated in $[5,6,9,22]$ are some of the most used general allometric equations in Africa for the purpose of biomass and carbon stock assessments. The one in [9] is particularly used by many studies and has been the best general model for carbon stock assessment so far [22]. Therefore, allometric equation [9] was used for this study is:

$$
\mathrm{Y}(\mathrm{kg})=\exp (-2.187+(0.916 * \ln (\rho \mathrm{D} 2 \mathrm{H})))
$$

Where, $\mathrm{Y}=$ tree biomass, $\mathrm{H}=$ tree height $(\mathrm{m}), \mathrm{D}=\mathrm{DBH}$ (cm) and $\rho=$ Wood density $\left(\mathrm{kg} \mathrm{m}^{-3}\right)$. While DBH and tree height are directly measured, wood density of species is obtained from other studies and databases. Average wood density value of the known species was used for species which wood density was not found.

Fresh weight of all the undergrowth had been measured in the $2 \mathrm{~m} * 2 \mathrm{~m}$ subplot and a small sample of known weight were taken for dry matter analysis. Regeneration was counted in this subplot. Tree biomass and respective carbon stock were calculated using allometric equations, and dry matter content of the undergrowth was determined after oven drying the fresh undergrowth sample and converting that proportionally to the $2 \mathrm{~m} * 2 \mathrm{~m}$ subplot and hectare levels. Therefore, the AGB is the sum of the two vegetation biomasses. Then the AGB carbon is calculated from the AGB using a biomass-carbon conversion factor of 0.5 [29].

ii. Belowground biomass (BGB) carbon

Below ground biomass carbon is directly derived from aboveground vegetation carbon using known conversion factors. Below ground root biomass is estimated using root to shoot ratio which varies 20 to $50 \%$ depending on species. However, for carbon accounting purposes conservative values are recommended. Accordingly, 24\% was used as a conversion factor for belowground biomass from above ground biomass as also recommended by other authors [8].

$$
\mathrm{BGB}=\mathrm{AGB} \times 0.24
$$

\section{iii. Dead wood carbon}

Dead wood carbon was estimated by applying general log volume estimation techniques using Smalian formula, and converting estimated volume to biomass and then to carbon.

$$
\mathrm{V}=\mathrm{f}(\mathrm{Ds} 2+\mathrm{Dl} 2) * \mathrm{~L} / 2
$$

Where: $\mathrm{V}=$ volume of the wood $\left(\mathrm{m}^{3}\right)$, Ds $=$ small diameter $(\mathrm{cm}), \mathrm{Dl}=$ large diameter $(\mathrm{cm}), \mathrm{L}=$ length $(\mathrm{m}), \mathrm{f}=$ adjustment factor $=0.00007854$.

\section{iv. Carbon Stocks in the Litter Biomass}

The litter layer is defined as all dead organic surface material on top of the mineral soil. Some of this material will still be recognizable (for example, dead leaves, twigs, dead grasses and small branches). The following formula was used to determine litter carbon stock of the study area. The total dry weight was determined in the laboratory after oven drying of the sample. Oven-dried samples were taken in preweighed crucibles. The samples were ignited at $550{ }^{\circ} \mathrm{C}$ for one hour in furnace. After cooling, the crucibles with ash were weighed and percentage of organic carbon was calculated.

$$
\mathrm{LB}=\frac{\text { Wfield }}{\mathrm{A}} * \frac{\text { Wsub_sample (dry) }}{\text { Wsub_sample (fresh) }} * \frac{1}{10,000}
$$

Where: $\mathrm{LB}=$ Litter biomass $\left(\mathrm{t} \mathrm{ha}^{-1}\right)$; $\mathrm{W}$ field $=$ weight of wet field sample of litter sampled within an area of size $1 \mathrm{~m}^{2}$ (g); $\mathrm{A}=$ size of the area in which litter were collected (ha); Wsub_sample $($ dry) $=$ weight of the oven-dry sub-sample of litter taken to the laboratory to determine moisture content (g), and Wsub_sample (fresh) = weight of the fresh sub_sample of litter taken to the laboratory to determine moisture content $(\mathrm{g})$.

Carbon stock in litter biomass was then determined using the following formula:

$$
\mathrm{CL}=\mathrm{LB} \times \% \mathrm{C}
$$

Where: $\mathrm{CL}=$ total carbon stocks in the litter in $\mathrm{tha}^{-1}, \% \mathrm{C}$ $=$ carbon fraction determined in the laboratory [36].

v. Soil organic matter

Soil organic matter contributes to more than $50 \%$ of the forest carbon stock in some forest types [40]. In some conditions the soil carbon stock is less dynamic and hence is less interesting to carbon stock assessment although it is the largest forest carbon pool. However, when there is high anthropogenic impact on the soil, particularly when there is a land use change, it is important to address the soil carbon content change related with land use changes. 
In the current study, soil organic carbon (SOC) was assessed as there is dynamic process of land use change, forest land being converted to agriculture or grazing field, and hence it was found important to assess SOC content. Soil samples were taken at four corners of the $10 \mathrm{~m} * 10 \mathrm{~m}$ subplot using $10 \mathrm{~cm}$ diameter core sampler to a depth of $30 \mathrm{~cm}$. The four subsamples were then mixed together and weighed for the soil bulk density determination. Then a composite sample of $100 \mathrm{~g}$ was taken. Soil bulk density has been determined by drying soil samples in oven at $103^{\circ} \mathrm{C}$ for 24 hours. Then, SOC was determined following the loss-on-ignition [36] method and the calculations were made as follows:

$$
\mathrm{BD}=\frac{\text { Wav.dry }}{\mathrm{V}}
$$

Where: $\mathrm{BD}=$ bulk density of the soil sample per the quadrant, Wav. dry = average dry weight of soil sample per the quadrant, $\mathrm{V}=$ volume of the soil sample in the core sampler auger in $\mathrm{cm}^{3}$

$$
\mathrm{SOC}=\mathrm{BD} * \mathrm{~d} * \% \mathrm{C}
$$

Where: $\mathrm{SOC}=$ soil organic carbon stock per unit area $(\mathrm{t}$ $\left.\mathrm{ha}^{-1}\right), \mathrm{BD}=$ soil bulk density $\left(\mathrm{g} \mathrm{cm}^{-3}\right), \mathrm{d}=$ the total depth at which the sample was taken $(30 \mathrm{~cm})$, and $\% \mathrm{C}=$ Carbon concentration (\%)

\section{vi. Estimation of Total Carbon Stock}

The total carbon stock is calculated by summing the carbon stock densities of the individual carbon pools. Accordingly, carbon stock density of a study area is:

$$
\mathrm{CT}=\mathrm{AGC}+\mathrm{BGC}+\mathrm{DWC}+\mathrm{LC}+\mathrm{SOC}
$$

Where: $\mathrm{CT}=$ Total Carbon stock for all pools $\left(\mathrm{t} \mathrm{ha}^{-1}\right)$, AGC $=$ above ground carbon stock $\left(\mathrm{t} \mathrm{ha}^{-1}\right), \mathrm{BGC}=$ below ground carbon stock $\left(\mathrm{t} \mathrm{ha}^{-1}\right), \mathrm{LC}=$ litter carbon stock $\left(\mathrm{t} \mathrm{ha}^{-1}\right)$ and $\mathrm{SOC}=$ soil organic carbon $\left(\mathrm{t} \mathrm{ha}^{-1}\right)$. The total carbon stock was then converted to tons of $\mathrm{CO}_{2}$ equivalent by multiplying it by 3.67 as stated by [37].

\section{Results and Discussion}

\subsection{Land Cover Change}

As the satellite image analysis of this study revealed, the cultivated and overgrazed land has increased from $20 \%$ in 1972 to $48 \%$ in 2013 (Figures 1 and 2). As a result, the AMF and AAWL have shrunk by nearly $50 \%$. The AMF and AAWL land have been shrinking, on average, by 118.4 and 200.8 ha per annum, respectively. A future projection using a simple linear model (equation 9 and 10) developed from the general land cover change that has been prevailed from satellite image analysis indicated 73ha and 251.3ha of annual deforestation in the AAWL and AMF zones, respectively. If this rate of deforestation continues, it will take only 71 and 49 years for the AMF and AAWL, respectively, to be completely lost if the management is not improved.

$$
\begin{aligned}
& \operatorname{AMF}(\text { in ha })=8268-72.9 x \\
& \text { AAWL (in ha) }=22790.4-251.3 x
\end{aligned}
$$

Where; $x$ is the number of years starting from 1972.

However, with increasing population and diminishing resources, rate of deforestation will increase and it may not take that long unless swift management approaches are implemented on the ground.

According to [44] the analysis of land-use/land-cover change and knowing its dynamics is a fundamental tool for adoption of conservation strategies within hotspot sites like protected areas. The phenomenon of forest loss in the nation seems to be quite common as outlined by some other researchers in different parts of the country $[28,18,19]$. The finding of the current study is also in consistent with the outcome of those researchers, but what is surprising about this finding is that the situation has happened in a protected area. Therefore, this is an alarming sign for improved and more effective conservation measures to be taken soon. Agricultural land has been expanding at the expense of the natural vegetation with a pressure both from within inhabitants and adjacent communities. The conversion of forested areas to cropland has been also a serious issue globally particularly from 1950s onward [32]. In the current study area $80 \%$ of the total park is directly affected by human activities such as settlement, cultivation, grazing and extraction of wood for fuel and construction [21]. Such activities will be catastrophic to the grass resource base and grass species diversity in the park. This will also significantly affect not only the grazing field, but the regeneration capacity of forest and woodland zones. The side effect of grazing on the regeneration capacity of forests has already been observed in this study. In the high forest areas far from villages, grazing is common experience and regeneration has already been affected. Since other interests like agricultural land expansion will also increase, the potential grazing land will shrink adding more grazing pressure on grasslands and forests, which will ultimately lead to forest degradation and then to land degradation. Fuel wood collection and selective logging of construction wood, together with grazing are primary factors for the forest degradation in the park.

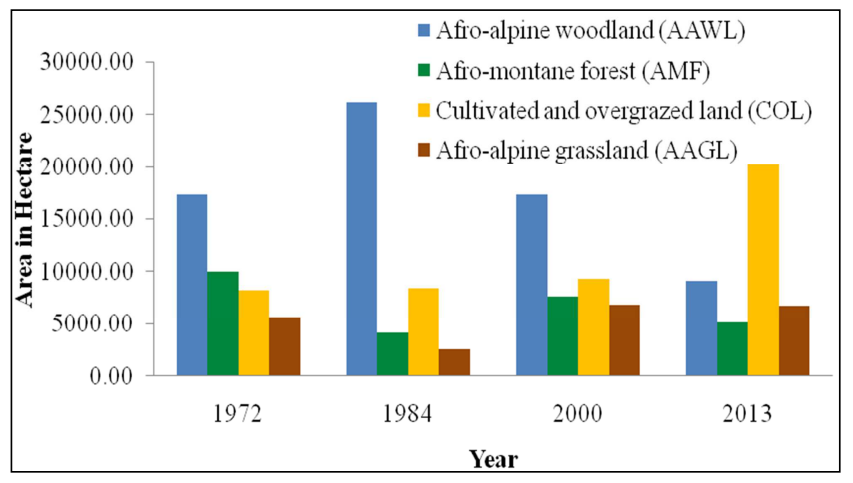

Figure 1. Land cover change trend of SMNP. 


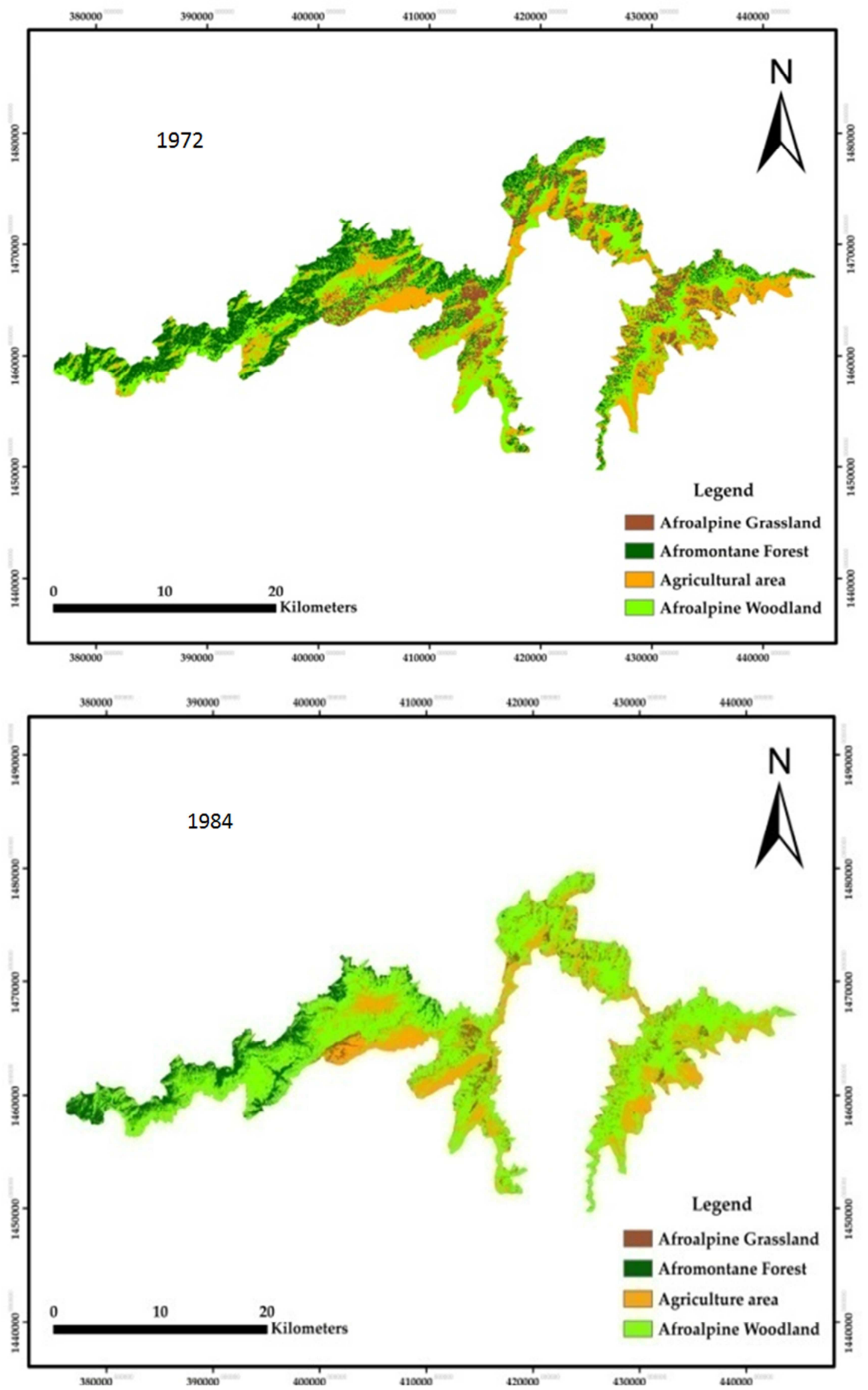



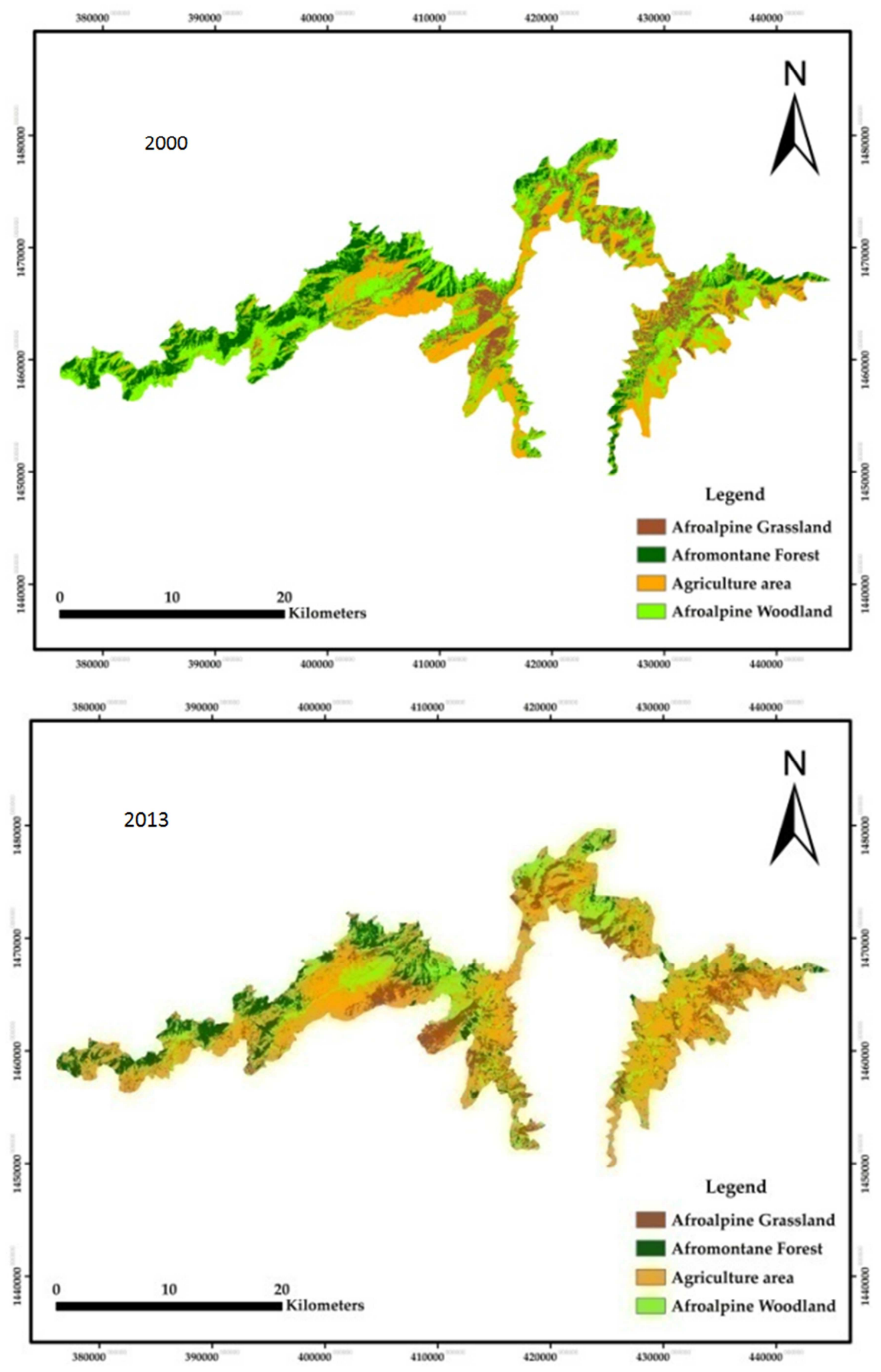

Figure 2. Land cover change of SMNP from 1972 up to 2013. 


\subsection{Carbon Stock of SMNP}

One of the important points regarding carbon management is to identify the carbon pool that has high stock as well as one that is highly dynamic and sensitive. As seen in table 1 and figure 3 below, most of the carbon stock is concentrated in three carbon pools: Aboveground, belowground and soils. $\mathrm{AGB}$, is a pool that holds about $34.4 \%$ of the forest carbon stock and hence it is the second largest pool next to the SOC which holds about $55.2 \%$. The third largest pool is BGB, which holds $8.3 \%$ of the total carbon stock. AGB and BGB together constitute $42.7 \%$ of the total carbon stock.

Therefore, the tree component is the largest carbon pool next to soil which implies that removal of trees is apparently removal of the bulk of carbon stock. The other two carbon pools contained less amount of carbon where Deadwood Biomass (DWB) and Litter Biomass (LB) both together contributed only $2.2 \%$. Conservation of forests for sustaining their existing carbon stock and future sequestration potential; assisting regeneration has to be the central focus of any carbon management project.

Table 1. Summary of mean carbon stock of aboveground, belowground, litter, deadwood and soil (ton/ha) of the study site.

\begin{tabular}{lllllll}
\hline \multirow{2}{*}{ Total N } & \multicolumn{5}{c}{ Different Carbon Pools } \\
\cline { 2 - 7 } & AGC t/ha & BGC t/ha & DWC t/ha & LC t/ha & SOC t/ha & Total C t/ha \\
\hline 40 & $57.83(14.13)$ & $13.88(3.39)$ & $2.77(1.11)$ & $0.85(0.34)$ & $92.7(8.61)$ & $168.02(21.79)$ \\
\hline
\end{tabular}

Numbers in bracket are standard error

In this study on average soil carbon was found to be the main contributor of the overall carbon stored in the study area. This finding is consistent with the report of [20] that states soil is the largest pool of organic carbon in the terrestrial biosphere, and hence, minor changes in SOC storage can impact atmospheric carbon dioxide concentrations.

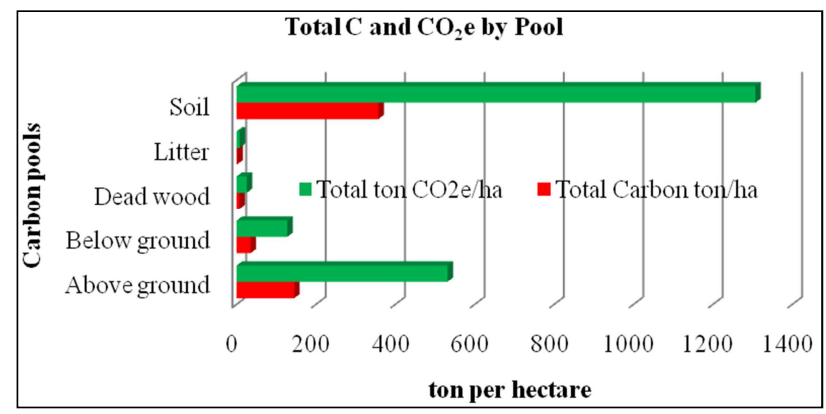

Figure 3. Total carbon and carbondioxide equivalent of the study site by pools.
When biomass accumulation and carbon storage was evaluated from land cover point of view, AMF was found to be the largest reservoir by storing nearly half $(47.5 \%)$ of the total carbon stock in the area followed by the AAGL (22\%) and AAWL (20.9\%) as a second and third carbon reservoir respectively. The least carbon storage was observed in COL (9.6\%) zone. Similarly, the large amount of carbon observed in AAGL zone was obtained from SOC may be as a result of high and rapid decomposition rate of the grass material and its incorporation to the soil as organic matter. From the table 2 and figure 4 it can be seen that land cover zones with trees and grass vegetations are found to be the most important depositors of biomass and carbon; hence it is evident that conversion of any form of natural vegetation to cultivated and overgrazing field will result in reduced AGC, BGC and SOC content which will affect the general holding capacity and sustainability of the area.

Table 2. Summary of mean carbon stock of aboveground, belowground, litter, deadwood and soil (ton/ha) of the four land covers of the study site.

\begin{tabular}{llllllll}
\hline \multirow{2}{*}{ Zone (Land cover) } & \multirow{2}{*}{ Total N } & \multicolumn{5}{c}{ Different Carbon Pools } \\
\cline { 3 - 8 } & & AGC t/ha & BGC t/ha & DWC t/ha & LC t/ha & SOC t/ha & Total C t/ha \\
\hline AAWL & 10 & 20.98 & 5.04 & 0.52 & 0.00 & 87.58 & 114.12 \\
AMF & 10 & 123.35 & 29.60 & 6.40 & 2.13 & 97.90 & 259.38 \\
AAGL & 10 & 0.80 & 0.19 & 0.00 & 0.00 & 119.36 & 120.36 \\
COL & 10 & 0.00 & 0.00 & 0.00 & 0.00 & 52.21 & 52.21 \\
\hline
\end{tabular}

The corresponding carbondioxide equivalent $\left(\mathrm{CO}_{2} \mathrm{e}\right)$ was calculated for all land cover zones and all carbon pools (figure 3 and 4 ) by multiplying the amount of carbon by 3.66 value, and it followed the same trend for all land cover zones and pools like that of carbon storage since it was derived using a constant figure. Considering the AMF land cover only for comparison with others report the following discussions were made. The AGC of AMF of this study is comparable to those reported for the global above ground carbon stock in tropical dry and wet forests that ranges between 13.5 to $122.85 \mathrm{t} \mathrm{ha}^{-1}$ and 95 to $527.85 \mathrm{t} \mathrm{ha}^{-1}$, respectively [34]. Yet this finding is similar to [43] who reported $122.85 \mathrm{t} \mathrm{ha}^{-1}$ AGC for selected church forests; and [30] obtained $133 \mathrm{t} \mathrm{ha}^{-1}$ AGC for Menagesha Suba state forest. However, it shows variation from the findings of [33] that obtained $306 \mathrm{t} \mathrm{ha}^{-1}$ of AGC for Tara Gedam forests and [1] found $237.75 \mathrm{t} \mathrm{ha}^{-1}$ of $\mathrm{AGC}$ for mount Zequalla Monastery forest. Also the AGB value of this study (246.7 t $\mathrm{ha}^{-1}$ ) is a bit lower than the AGB of the Amazonian Brazil forests ranged between 290- $495 \mathrm{t} \mathrm{ha}^{-1}$ [3]. The BGB and $\mathrm{BGC}$ have similar trend with that of the aboveground values due to the fact that it is derived from the aboveground results 
using a constant conversion factor 0.24 [8]. The variation is perhaps due to methodological differences referring to the sample size and models or allometric equations used to calculate the biomass and also site variations. The result of carbon stock in litter layer for AMF is $2.13 \mathrm{t} \mathrm{ha}^{-1}$ and this value is larger than the findings of [33] and [42] 0.9 and $0.017 \mathrm{t} \mathrm{ha}^{-1}$ respectively; whereas it is smaller than the findings of [30] and [43] 5.26 and $4.95 \mathrm{t} \mathrm{ha}^{-1}$ respectively. The result of carbon stock in litter layer for AMF is $2.13 \mathrm{tha}$ ${ }^{1}$ and this value is larger than the findings of [33] and [42] 0.9 and $0.017 \mathrm{t} \mathrm{ha}^{-1}$ respectively; whereas it is smaller than the findings of [30] and [43] 5.26 and $4.95 \mathrm{tha}^{-1}$ respectively.

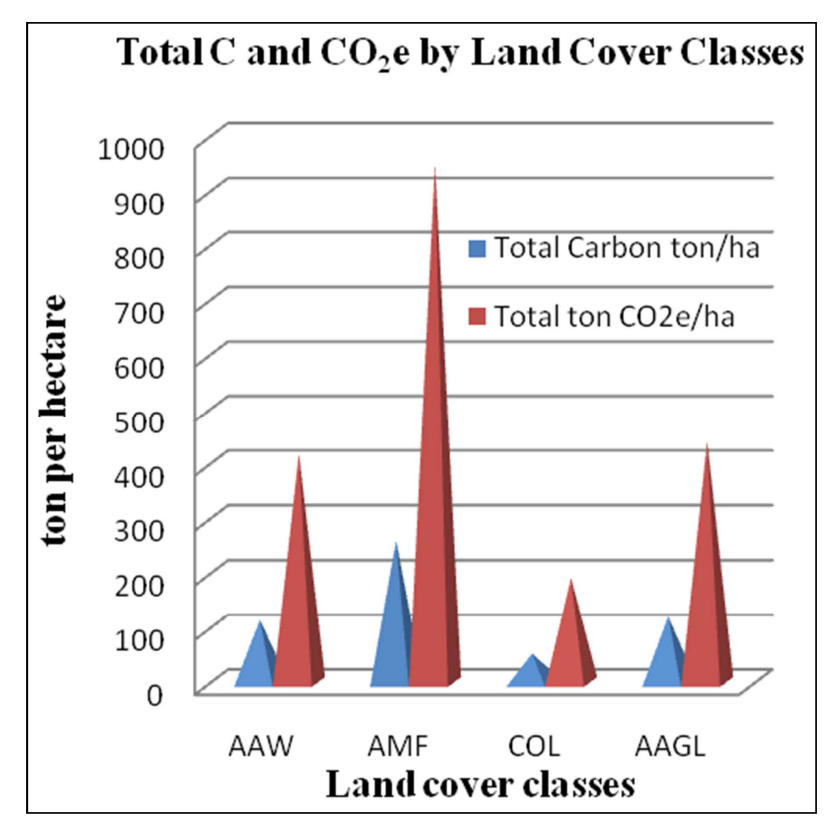

Figure 4. Total carbon and carbondioxide equivalent of different zones/land cover

\subsection{Carbon Stock and Tree Species Diversity}

Biodiversity is one important issue in the management of forests for carbon dioxide sequestration and carbon stock purposes. It is generally required if there is direct relationship between diversity and carbon stock, so that the carbon stock management and biodiversity conservation can go hand in hand. However, there is no general conclusion reached at so far regarding biodiversity and carbon stock relation. As it is seen in figure 5 below, a linear regression between Shannonwiener diversity index and total carbon and AGC was calculated for the observations within the AMF land cover and as such no clear and strong relationship was seen for the total $\mathrm{C}\left(\mathrm{R}^{2}=0.242\right)$, but it appeared that the stored carbon tends to decrease as the Shannon diversity index increases. The relation seems to be stronger $\left(R^{2}=0.337\right)$ for Shannon diversity index and AGC in AMF. The more diverse the forest implies less carbon stock. The AMF has the highest carbon stock per hectare. This could be due to the fact that in the AMF zone, there are big trees which occupy the upper canopy and discourage other trees not to grow. In addition, the larger tree sizes are the fewer in number so that reducing the diversity index. In this context, it is important that some gap is created in the AMF zone either naturally or artificially so that biodiversity is promoted, which has direct side effect on the carbon stock. The diversity index was not calculated for the AAWL zone since in almost all the plots only one tree species, Erica arborea, was observed. In fact, the relation between tree species diversity and amount of carbon stored needs to be studied in detail and case by case using more robust data. So far some researchers studied the issue, but their findings vary and might be difficult to draw a general conclusion. For instance, [10] reported that forest carbon storage depends on species composition and on the way in which species are lost. [31] in their study of tree species diversity and AGB revealed that there is a complex and highly variable relationship between biomass and species diversity within Central African rainforests. Some plots with high diversity have relatively low biomass, and some plots with low diversity had high biomass.

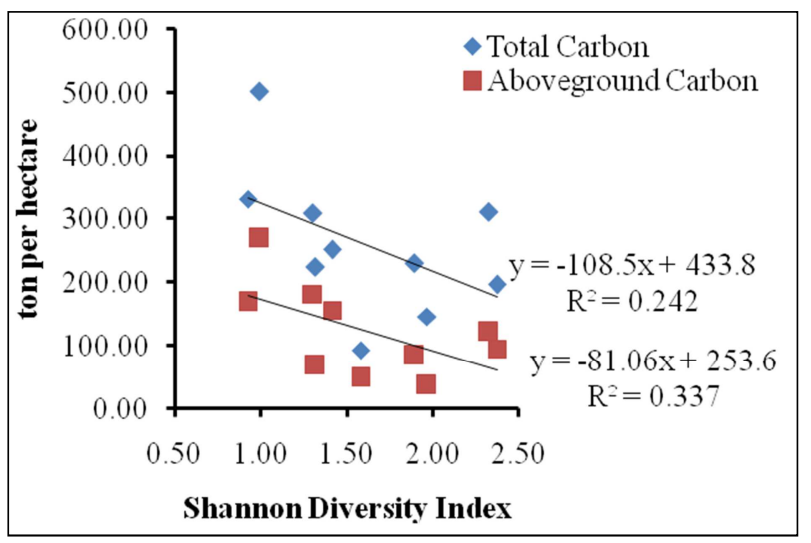

Figure 5. Relationship between carbon and tree species diversity for the AMF land cover.

\section{Conclusion}

Consensus over climate change phenomena is reached globally and a wide range of adaptation and mitigation measures have been taken. Enhancing carbon sequestration potential of forests and other similar land use or land cover zones is one of the feasible mitigation measures. Hence, carbon sequestration within protected areas is a valuable resource of GHG removals which would not be available if these protected areas were converted to other land use types. Even though, the management of the SMNP has strongly oriented towards the protection of wildlife and their habitat, there is high potential to address the climate change adaptation and mitigation issues as it still holds huge forest area that has ample carbon stock. In the study area land cover change dynamics is very much significant. It was found that there is an annual degradation of $73 \mathrm{ha}$ and $251.3 \mathrm{ha}$ in the AMF and AAWL zones respectively. AMF zone has high stock of carbon particularly in the AGB and the highest tree species diversity with different storey structure. The AAGL zone holds large carbon stock in the soil and grass species diversity. Therefore, conservation of these zones in particularly and protected areas 
in general is relevant in meeting double objectives of emission reduction from deforestation and also carbon sequestration as well as biodiversity conservation. Detailed investigation with robust data from other similar protected areas would reinforce these findings.

\section{Acknowledgement}

The authors would like to thank Population Health and Environment Ethiopia Consortium (PHEEC) for supporting the project financially through the Strategic Climate Initiative (SCIP) project.

\section{References}

[1] Abel G., Teshome S. and Tesfaye B. 2014. Forest Carbon Stocks in Woody Plants of Mount Zequalla Monastery and It's Variation along Altitudinal Gradient: Implication of Managing Forests for Climate Change Mitigation. Science, Technology and Arts Research Journal. 3(2): 132-140.

[2] Adugna F., Teshome S., and Mekuria A. 2013. Forest Carbon Stocks and Variations along Altitudinal Gradients in Egdu Forest: Implications of Managing Forests for Climate Change Mitigation. Science, Technology and Arts Research Journal. 2(4): 40-46.

[3] Alves L. F., Vieira S. A., Scaranello M. A., Camargo P. B., Santos F. A. M., Joly C. A. and Martinelli L. A. 2010. Forest structure and live aboveground biomass variation Along an elevational gradient of tropical Atlantic moist forest. Forest Ecology Management 260: 679-691.

[4] Broadmeadow M., and Robert M. 2003. Forests, Carbon and Climate Change: The UK contribution. Forestry Commission Bulletin 125. Forestry Commission, Edinburgh.

[5] Brown S. A. J., Gillespie J. R. and Lugo A. E. 1989. Biomass estimation methods for tropical forests with application to forest inventory data. Forest Science 35(4): 881-902.

[6] Brown S. 1997. Estimating Biomass and Biomass Change of Tropical Forests: A Primer. UN FAO Forestry Paper, Rome 134:55.

[7] Busby G. B. J., Busby J. S. E., Grant J., Hoolahan R. A. and Marsden C. D. 2006. The Lone Wolf Project Final Report: An expedition to the Simien Mountains, 29 ${ }^{\text {th }}$ June to 2005. Unpublished expedition report. 127 pages.

[8] Cairns M., S. Brown E. H. Helme and G. A. Baumgardner. 1997. Root biomass allocation in the world's upland forests. Oeclogia 111(1).

[9] Chave J., Andalo C., Brown S, Cairns M. A., Chambers J. Q., Eamus D, Folster H, Fromard F, Higuchi N., Kira T., Lescure J. P., Nelson B. W., Ogawa H., Puig H., Riera B., Yamakura T. 2005. Tree allometry and improved estimation of carbon stocks and balance in tropical forests. Oecologia 145: 87-99.

[10] Daniel E. B., Fabrice C., Jason C. B., Robert K. C., Ivette P., Oliver L. P., Mahesh S., and Shahid N. 2005. Species Loss and Aboveground Carbon Storage in a Tropical Forest. SCIENCE VOL 310. www.sciencemag.org
[11] Dudley N., S. Stolton, A. Belokurov, L. Krueger, N. Lopoukhine, K. MacKinnon, T. Sandwith and N. Sekhran [editors] 2010. Natural Solutions: Protected areas helping people cope with climate change, IUCNWCPA, TNC, UNDP, WCS, The World Bank and WWF, Gland, Switzerland, Washington DC and New York, USA.

[12] Edwards S., Mesfin T. and Hedberg I. [editors] 1995. Flora of Ethiopia and Eritrea, Vol. 2, Part 2: Canellaceae to Euphorbiaceae. The National Herbarium, Addis Ababa, Ethiopia and the Department of Systematic Botany, Uppsala, Sweden.

[13] Edwards S., Sebsebe D. and Hedberg I. [editors] 1997. Flora of Ethiopia and Eritrea, Vol. 6: Hydrocharitaceae to Arecaceae. The National Herbarium, Addis Ababa, Ethiopia and the Department of Systematic Botany, Uppsala, Sweden.

[14] Edwards S., Mesfin T. and Hedberg I. [editors] 2000. Flora of Ethiopia and Eritrea, Vol. 2, Part 1: Magnoliaceae to Flacourtiaceae. The National Herbarium, Addis Ababa, Ethiopia and the Department of Systematic Botany, Uppsala, Sweden.

[15] Estrada M. 2011. Standards and methods available for estimating project-level REDD+ carbon benefits: reference guide for project developers. Working Paper 52. CIFOR, Bogor, Indonesia.

[16] Falch F. and Keiner M. 2000. Simien Mountains National Park Management plan. Final Draft (unpublished) Amhara National Regional State, Bahir Dar.

[17] Friis L. and Vollesen K. 1984. Additions to the flora of Ethiopia. - Willdenowia 14: 355-371. ISSN 0511-9618.

[18] Gete Z. and Hurni H. 2001. Implications of land use and land cover dynamics for mountain resource degradation in the northwestern Ethiopian highlands. Mountain Research and Development 21(2): 184-191.

[19] Gessesse Dessie and Kleman, J. 2007. Pattern and Magnitude of Deforestation in the South Central Rift Valley Region of Ethiopia. Mountain research and development 27(2): 162-168.

[20] Girmay G., Singh B. R., Mitiku H., Borresen T., And Lal R. 2009. Carbon Stocks In Ethiopian Soils In Relation To Land Use And Soil Management. Land Degrad. Develop.19: 351367.

[21] GMP. 2009. Simien Mountains National Park General Management Plan, 2009-2019.

[22] Henry M., Picard N., Trotta C., Manlay R. J., Valentini R., Bernoux M. and Saint-André L. 2011. Estimating tree biomass of sub-Saharan African forests: a review of available allometric equations. Silva Fennica 45(3B): 477-569.

[23] IPCC (Intergovernmental Panel on Climate Change). 2000. Land Use, Land-Use Change, and Forestry. Edited by Watson R. T, Nobel I. R, Bolin B, Ravindranath N. H, Verardo D. J, Dokken D. J, Cambridge University Press, Cambridge.

[24] IPCC. 2007a. Highlights from Climate Change 2007. The Physical Science Basis. Summary for Policy Makers. Contribution of Working Group I to the Fourth Assessment Report of the Intergovernmental Panel on Climate Change. Cambridge University Press, Institute of Terrestrial Ecology, Edinburgh. pp. 545-552. 
[25] IPCC. 2007b. Facts on climatic change. A summary of the 2007 assessment report of IPCC. Cambridge University Press, Cambridge, UK.

[26] Jandl R., Rasmussen K., Tomé M., Johnson D. W. 2006. The role of Forests in carbon Cycles, Sequestration and Storage. Issue 4. Forest management and carbon sequestration. Federal Research and Training Centre for Forests, Natural Hazard and Landscape (BFW), Vienna, Austria.

[27] Julia Grunenfeld 2005. Livestock in the Simien Mountains, Ethiopia. Its role for the livelihoods and landuse of local small holders. Masthers Thesis, University of Berne.

[28] Kebrom T. and Hedlund L. 2000. Land cover changes between 1958 and 1986 in Kalu district, southern Wello, Ethiopia. Mountain Research and Development 20(1): 42-51.

[29] Liu X., Ekoungoulou R., Loumeto J. J., Ifo S. A., Bocko Y. E., Koula F. E., 2014. Evaluation of carbon stocks in above- and below-ground biomass in Central Africa: case study of Lesiolouna tropical rainforest of Congo. Biogeosciences Discuss., 11, 10703-10735.

[30] Mesfin S. 2011. Estimating and Mapping of Carbon Stocks based on Remote Sensing, GIS and Ground Survey in the Menagesha Suba State Forest. M. Sc. Thesis, Addis Ababa University, Addis Ababa.

[31] Michael D., Cristina B., Ervan R. and Terry C. H. S. 2013. Relationships between tree species diversity and aboveground biomass in Central African rainforests: implications for REDD. Environmental Conservation 41 (1): 64-72.

[32] Millennium Ecosystem Assessment. 2005. Ecosystems and human well-being: biodiversity synthesis. World Resources Institute, Washington, DC.

[33] Mohammed G. 2013. Forest carbon stocks in woody plants of Tara Gedam forest and its variations along environmental factors: Implication for climate change mitigation, in South Gondar, Ethiopia.

[34] Murphy P. G. and Lugo A. E. 1986. Structure and biomass production of a dry tropical forest in Puerto Rico. Biotropica 18: 89-96.

[35] Pan Y., Birdsey R. A., Fang J., Houghton R., Kauppi P. E., Kurz W. A., Philips O. L., Schivdenko A., Lewis S. L.,
Canadell J. G., Ciasis P., Jackson R. B., Pacala S. W., McGuire A. D., Piao S., Rautiainen A., Sitch S. and Hayes D. 2011 A large and persistent carbon sink in the world's forests. Science 333: 988-993.

[36] Pearson T., Walker S. and Brown S. 2005. Sourcebook for land-use, land-use change and forestry projects. Winrock International and the Bio-carbon fund of the World Bank. Arlington, USA, pp. 19-35.

[37] Pearson T. R., Brown S. L. and Birdsey R. A. 2007. Measurement guidelines for the sequestration of forest carbon: Northern research Station, Department of Agriculture, Washington, D. C, pp. 6-15.

[38] Per-Marten S., Felix H., Christoph L., Ann-Catrin F. and Hermann F. J. 2014. Higher subsoil carbon storage in speciesrich than species-poor temperate forests. Environmental Research Letters 9 (2014).

[39] Petit J., Jouzel J., Raynauud D., Barkov N. I., Barnola J. M., Basile I., Bender M., Chappelaz J., Davis M., Delaygue G., Delmote M. 1999. Climate and atmospheric history of the past 420,000 years from the Vostok ice core in Antarctica. Nature 339: 429-436.

[40] Roshetko M., Rodel D. L. and Marian S. D. A. 2007. SMALLHOLDER AGROFORESTRY SYSTEMS FOR CARBON STORAGE. Mitigation and Adaptation Strategies for Global Change. Springer 12: 219-242.

[41] Sundquist E., Robert B., Stephen F., Robert G., Jennifer H., Yousif K., Larry T. and Mark W. 2008. Carbon Sequestration to Mitigate Climate Change. U. S. Geological Survey, New York, USA, pp. 1-4.

[42] Tibebu Y., Teshome S. and Eyale B. 2014. Forest Carbon Stocks in Lowland Area of Simien Mountains National Park: Implication for Climate Change Mitigation. Science, Technology and Arts Research Journal. 3(3): 29-36.

[43] Tulu T. 2011. Estimation of carbon stock in church forests: implications for managing Church forest for carbon emission reduction.

[44] Turner II B. L., Meyer W. B., Skole D. L. 1994. Global landuse/land-cover change: Towards an integrated program of study. Ambio 23 (1), 91-9. 